\title{
Unusual Upper Emsian Tabulata and Rugosa from the Floresta Formation of Columbia
}

\author{
Yves Plusquellec
}

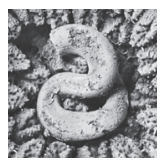

\begin{abstract}
The study of a small fauna of columbian corals in the Floresta Formation, upper Emsian, permits the recognition of the new species Granulidictyum (G. alechinskyi) associated with an Hicetes gallery (first record of the Granulidictyum/ Hicetes system), the presence of Paleofavosites sp. which constitutes a new record of a microlamellar favositid in the Devonian and a new species of the recently erected genus of the discoid coral Devonodiscus. In addition, the presence of Amazonodictyum amazonicum is recorded for the first time in Columbia. - Key words: Tabulata, Granulidictyum, Amazonodictyum, Paleofavosites, Rugosa, Devonodiscus, Devonian, Columbia, paleobiology.
\end{abstract}

Plusquellec, Y. 2019. Unusual Upper Emsian Tabulata and Rugosa from the Floresta Formation of Columbia. Bulletin of Geosciences 94(4), 441-454 (5 figures, 1 table). Czech Geological Survey, Prague. ISSN 1214-1119. Manuscript received June 27, 2019; accepted in revised form November 4, 2019; published online December 23, 2019; issued December 31, 2019.

Yves Plusquellec, Laboratoire de Paléontologie (UMR 6538 Domaines océaniques) Université de Bretagne Occidentale, UFR Sciences et Techniques, 6 avenue Le Gorgeu F-29283 Brest Cedex 3 (France); yves.plusquellec@) univ-brest.fr

Morzadec et al. (2015) provided a detailed study of the trilobites and inarticulate brachiopods from the Devonian Floresta Formation, eastern Cordillera of Columbia. The aim of the present work is to give some new data about the corals and to draw attention to the presence in South America of representatives of 1) an unusual Hicetesbearing specimen of Procteria (Granulidictyum) described as G. alechinskyi sp. nov. and 2) Devonodiscus, a discoid coral genus erected by Pedder (2019) with Devonodiscus latisubex Pedder, 2019 as type species.

\section{Stratigraphy}

The main geographic and stratigraphic data about the Devonian of Columbia are given by Morzadec et al. (2015) and it seems unnecessary to repeat this information. The specimens described and illustrated in this paper were collected by Racheboeuf in 2004 and 2006 in the Floresta Massif (about $125 \mathrm{~km} \mathrm{NE}$ of Bogota) in the Quebrada Monticelo section, lower part of the Floresta Formation (beds 5, 8 and 12, cf. Morzadec et al. 2015, fig. 2a).

Following Morzadec in Morzadec et al. (2015), the lower part of the Floresta Formation - and especially the beds 8 to 11 in which the trilobites have been collected are likely to be late Emsian in age (serotinus Zone). Among the species and genera identified by Morzadec in these levels, some are known to occur in the serotinus Zone: Anchiopsis armata from the Schoharie Grit in New
York state and Synphoria stemmata from the Bois Blanc Formation of Michigan. In addition, Morzadec (2015, pp. 332, 333) stated "Belenopyge contusa, as well as the genus Mannopyge, both occur in the Formosa Member of the Amherstburg Formation of Ontario, which is assigned to the late Emsian serotinus zone (Ludvigsen, 1987)". However, these are not exactly the words of Ludvigsen (1987, p. 677) which indicated - following Uyeno et al. (1982) - that the Formosa member can be assigned to the "Polygnatus serotinus Zone and possibly to the overlying P. costatus patulus Zone" i.e. uppermost Emsian. In addition, Johnson \& Klapper (1992, fig. 1) would have considered the Formosa Member to be patulus or partitus Zone.

As a result, if the lower part of the Floresta Formation is undoubtedly late Emsian in age, it could be a little younger than stated by Morzadec and may reach the serotinus/patulus boundary. However, we have to bear in mind that the trilobites allowing the stratigraphic attribution are located in beds 8 to 11 and that bed 5 (one of the coral-bearing level) lies a little more than $3 \mathrm{~m}$ below.

\section{Systematic palaeontology}

As far as the author knows, the first mention of Devonian corals from the Floresta fauna was given by Caster (1939) who wrote: "the calicinal imprint of a single tiny tetracoral has been found in our material. This seems probably to be Cyathophyllum bolivianum Kozlowski." Morales (1965) 
recognized, described and/or illustrated in the Floresta area Favosites sp. aff. F. hamiltonensis Hall, Heliophyllum sp. and Pleurodictyum americanum Roemer. Forero Suárez (1991) listed in the same localities Favosites hamiltoneniae, Chaetetes sp. (now referred to Porifera) and Heliophyllum sp.

Among the corals collected by Racheboeuf in the Floresta Formation, species of Devonodiscus and Procteria (Granulidictyum) are new to the Columbian Devonian whereas the so-called Pleurodictyum americanum and Heliophyllum were not found and "Favosites" attested by a single specimen.

The specimens are stored at the Laboratoire de Paléontologie, UFR Sciences \& Techniques, Université de Bretagne Occidentale, Brest, France under numbers LPB 16 714-718 and LPB 16722.

Subclass Tabulata Milne-Edwards \& Haime, 1850

Order Favositida Wedekind, 1937

Family Micheliniidae Waagen \& Wentzel, 1886

Subfamily Granulidictyinae Weyer, 1970

\section{Genus Procteria Davis, 1887}

Type species. - Procteria michelinoidea Davis, 1887.

\section{Subgenus Granulidictyum Schindewolf, 1959}

Type species. - Pleurodictyum granuliferum Schlüter, 1889.

Procteria (Granulidictyum) alechinskyi sp. nov.

Figures 1A-E, 2

Holotype. - LPB 16714.

Type horizon and locality. - Lower part of the Floresta Formation, upper Emsian; Quebrada Monticelo section, N-W of Tobasia, Columbia.

Material. - Five specimens, of which two with their complete proximal side and one with its complete distal side including Hicetes gallery. LPB 16714 , bed 5 or 8; LPB16 715 and LPB 16 716, bed 5; LPB 16717 and LPB16718, bed 8. Quebrada Monticelo section, Floresta Formation (upper Emsian).

Etymology. - Species dedicated to Pierre Alechinsky, artist of the COBRA movement whose acronym can evoke the snake-like path of Hicetes always present in this material. See also its etching "S Aspiré" printed in 1988.

Diagnosis. - Large species of Granulidictyum with numerous eucorallites, about 46 for a corallum diameter of $28 \mathrm{~mm}$, and numerous interstitial corallites. Calicinal bases of eucorallites with a diameter, measured along the corallum radius, of $c a .6 .7 \mathrm{~mm}$ and one at $90^{\circ}$ of $c a$. $3.5 \mathrm{~mm}$. Well-marked axial/radial structure occupying the calicinal base and appearing concave in natural mould, the initial area of which fits with that of the corallite. Scattered rather strong spines of unequal size on the calicinal bases. Hicetes present.

Description. - The corallum is rather well preserved (natural moulds), moderately large and clearly discoid.

Proximal side (lower surface): In natural mould, the proximal side is slightly convex, roughly circular and its surface covered by the prints of small granules regularly spread. The size and morphology of granules are either the same on the whole surface (Fig. 1E, C) or show a trend to be elongated toward the periphery of corallum (Fig. 1A). In addition, the diameter of granules is rather variable: small in LPB 16714 (holotype, Fig. 1A), medium in LPB 16715 (Fig.1D) and larger in LPB 16717 (Fig.1C).

The pores in the basal plate seem to be very scarce. Only one has been clearly recorded in specimen LPB 16715 between the infilling of a peripheral corallite and the proximal side to which it remains attached (Fig. 1D).

The proximal side is devoid of concentric growth lines but in some cases, on the margin of the corallum, wavy irregularities indicate the location of the corallite wall at the basal plate level (Fig. 1A lower left and 1C).

In specimen LPB 16714 (holotype, Fig. 1A) the foreign body to which the larva was attached remains unusually free, clearly visible - here it is the valve of a devonochonetid - whereas in LPB 16715 (Fig. 1D) the foreign body is buried within the skeleton and appears as a "ghost" on the proximal side indicating that the skeleton was fully covered by the living tissue.

Distal side (upper surface): In natural mould, the upper side is concave at the level of the calicinal bases and the central area is occupied by the mould of the gallery of Hicetes. Two categories of corallites can be distinguished 1) the eucorallites which calice bases reach the basal plate; in natural mould, when the specimen is complete they are the only one exposed and 2) the interstitial corallites situated between the former, their apex does not reach the basal plate, thus they can be seen only on incomplete or broken specimens.

Eucorallites: The outline of the corallites at the calicinal base level - although sometimes truncated by the gallery of Hicetes - is rhombic to irregularly polygonal in the central area of the corallum (adult corallites) becoming trapezoidal to triangular at the periphery (respectively subadult to juvenile corallites, see Plusquellec (2007, fig. 2c) for explanation of these categories). 

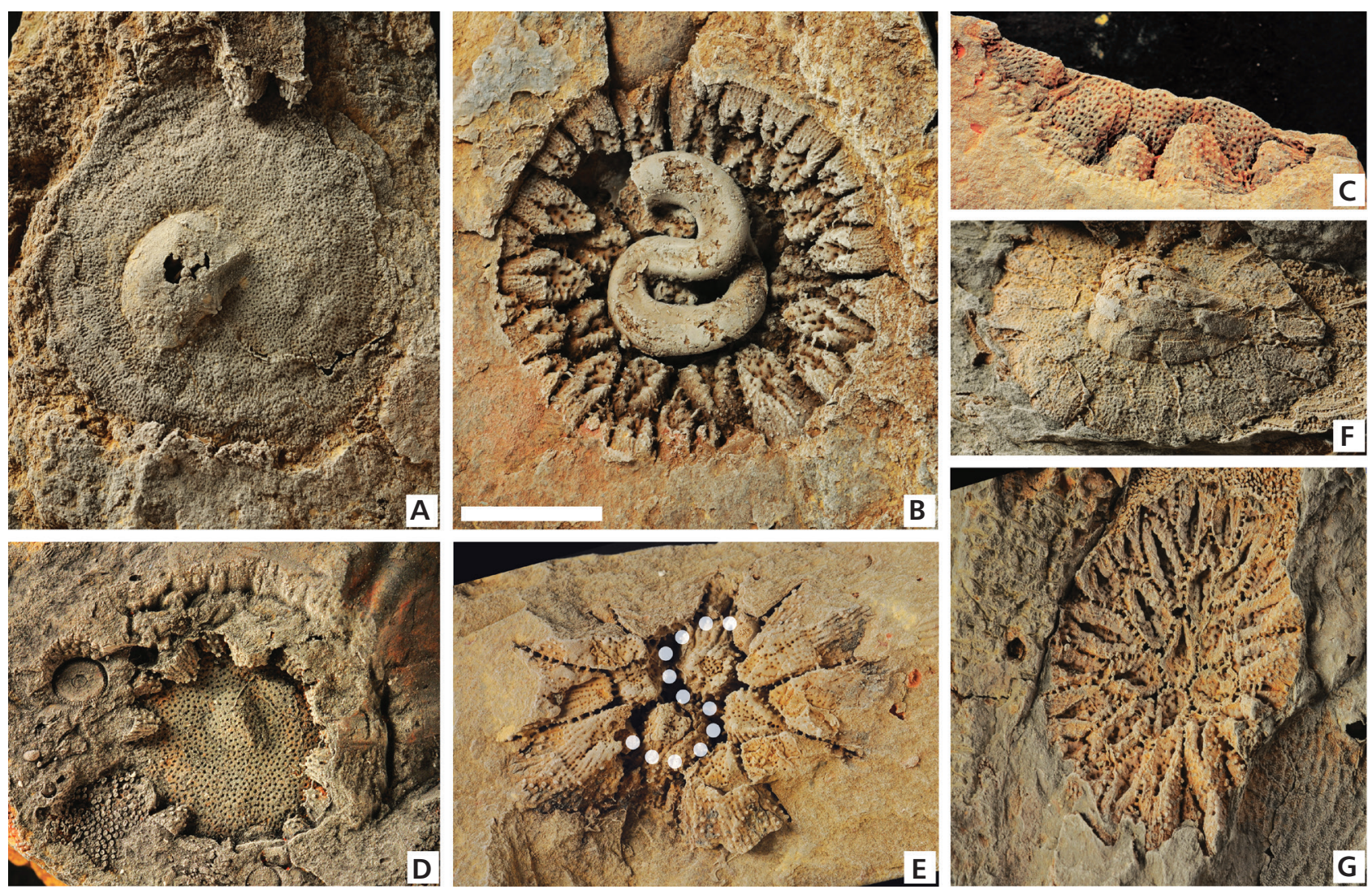

Figure 1. A, B, C, D, E-Procteria (Granulidictyum) alechinskyi sp. nov., lower part of the Floresta Formation, Quebrada Monticelo section, upper Emsian. Specimens in natural moulds; A, B - holotype LPB 16 714, A - proximal side, B - distal side; C, E - LPB 16 717, C - proximal side, E - distal side, dotted line as path of Hicetes; D - LPB 16 715, proximal side. $\bullet$ F, G - Procteria (Granulidictyum) sp. e.g. alechinskyi, lower Member of the Herrera Formation, Chillón, Almadén Syncline, lower Emsian. Specimen in natural mould; F - proximal side, note that the foreign body (Bivalvia) remains free; $\mathrm{G}$ - distal side, LPB 16 719. All specimens at the same magnification, scale bar $10 \mathrm{~mm}$.

In natural mould the central part of the eucorallite's bases appears clearly concave; however a flat area, bearing septal ridges, develops at the peripheral margin of subadult and juvenile corallites (Fig. 1B). In fact, this calicinal base morphology corresponds, in calcareous specimens, to a convex axial/radial structure the outline of which, at the calicinal base level is more or less rhombic to lanceolate, i.e. broad and roughly triangular in the half internal (or initial) area of the calicinal base, narrow in its peripheral part (Figs 1B, 2A). More precisely, in the initial area of the calicinal base, the outline of the axial structure fits with that of the corallite. This morphology is very similar to that of some Pleurodictyum problematicum Goldfuss, 1829 (see Fuchs \& Plusquellec 1982, fig. 6d-f and pl. 2, fig. 1) and the Columbian specimens belong in a way to a Pleurodictyum-like species.

The axial structure bears prints of some scattered, rather strong spines. They are not arranged along a radial median line (Fig. 2B-D) except in some cases at the very peripheral margin of the corallites.

Adjacent corallites are connected by mural pores appearing as cylindrical girders in mould. They belong to the wall pore category alias $\mathrm{P}_{2}$ (Plusquellec 1976, Powell \& Scrutton 1978).

Empty space corresponding to the wall is narrow at the calicinal base level as well as at the calicinal aperture.

The impression of more or less spiny septal ridges (narrow furrows in cast) alternate with moulds of broader interseptal furrows. They mainly belong to the major septal ridges, some short minor ones are only present at the peripheral margin of subadult corallites (Fig. 2B, C). It is interested to point out that, on both sides of the major ridge highlighting the plane of bilateral symmetry of the corallite (the cardinal ridge?), appears a major ridge and that is similar to the septal pattern known in the Rugosa.

Imprints of tabulae or tabellae are not recorded.

Interstitial corallites: They are numerous (but difficult to see!). The filling of their calice is conical and the apex reaches approximately half or a third of the depth of the eucorallites (Fig. 2D, top, on both sides of the axial structure). Interstitial corallites are connected to the eucorallites by numerous $\mathrm{P}_{2}$ mural pores, the mould of the single basal pore $\left(\mathrm{P}_{0}\right)$, opening at the apex, is often well 
exposed appearing as a rather long narrow "string". Septal ridges and small prints of spines are present.

Hicetes: The "worm" Hicetes is known within each colony although sometimes broken, thus the central S-shaped part of the gallery is missing. Two kinds of "S" are recorded: one right S (LPB 16717 , Fig. 1E) and three left S (LPB 16 714, Fig. 1B; LPB16 715; LPB16 718).

The presence of Hicetes in association with Procteria in unusual. It was described and illustrated for the first time in Procteria (Pachyprocteria) vermifera Plusquellec et al., 2011 from the lower Eifelian of the Gaspé Sandstones Group of Québec (Plusquellec et al. 2011).

Biometric data: The results of the biometric study are given in Tab. 1 and the measurements (in $\mathrm{mm}$ ) are taken as indicated in Plusquellec et al. (2011). Owing to the small number of specimens and their incompleteness, the biometric data are only indicative.

Discussion. - Generic and specific assignment: The morphology of the lower side of the basal plate is diagnostic of the genus Procteria Davis, 1887 whereas the size of the corallum (large), its rounded outline (not star-like), its thin wall, the lack of tabulae or tabellae and for a lesser part the presence of interstitial corallites allow assignment of our material to the sub-genus Granulidictyum Schindewolf, 1959.

Only a few species are assigned to Granulidictyum, such as Procteria (Granulidictyum) granuliferum (Schlüter, 1889); P. (Granulidictyum) sp. nov. (= Pleurodictyum problematicum var. richteri Weissermel, 1941a); P. (Granulidictyum) cornu Stumm, 1950; P. (Granulidictyum) elisabetae (May, 2006); P. (?Granulidictyum) gavaensis Plusquellec, 2007; P. (Granulidictyum) granuliferum morphotype "Bolast" Plusquellec, 2007 and P. (Granulidictyum) simplex Plusquellec, 2007 nomen nudum.

Brief review of these known species or forms: Granulidictyum simplex (upper Emsian of the Western Armorican Massif) and ?G. gavaensis (upper Lochkovian to lower Pragian of the Catalonian Coastal Ranges) are small forms with few eucorallites, calicinal bases devoid of axial structure, rather numerous and large basal plate pores, interstitial corallites lacking. The two species mainly differ by the size of the protocorallite.

Granulidictyum elisabetae (Emsian to Eifelian of the Aragonian Pyrenees) is a medium sized species (corallum diameter 13-14 mm) with calicinal bases bearing a well-marked and rather narrow radial structure ("longitudinal axial ridge" of Plusquellec \& Fernández Martínez 2007, legend of fig. 1a), large and closely spaced numerous mural pores as well as basal plate pores (May 2006, fig. 1c, d and Plusquellec \& Fernández Martínez 2007 , discussion p. 85 , fig. 1a). The presence or absence of interstitial corallites is not documented because the specimens are complete and not broken. In addition, May (2006) stated that "In the center of both coralla are foreign bodies that [he] cannot identify unequivocally. They are possibly tubes of Hicetes Clarke, 1908." In the specimen illustrated in fig. 1c (May 2006) this is - in my opinion an erroneous interpretation of the outline of the central corallite, whereas in his specimen of fig. 1d the central area is too badly preserved to provide useful data about Hicetes.

The case of Granulidictyum sp. nov. (alias P. problematicum var. richteri), ambiguously described by Weissermel (1941a) from the early upper Emsian of

Table 1. Procteria (Granulidictyum) alechinskyi sp. nov., biometric data.

\begin{tabular}{|c|c|c|c|c|c|}
\hline Specimen $\quad$ Biometric data & LPB 16714 & LPB 16715 & LPB 16716 & LPB 16717 & LPB 16718 \\
\hline Corallum diameter & $29 \times 28$ & $16.5 \times 15.0(?)$ & & & \\
\hline Height of corallum & & & ca. 3 & $3-4$ & ca. 4 \\
\hline Number of granules on proximal side & $975 / \mathrm{cm}^{2}$ & $710 / \mathrm{cm}^{2}$ & & & \\
\hline Number of corallites at basal plate level & $\begin{array}{l}43 \text { exposed, } \\
46-47 \text { estimated }\end{array}$ & & & & \\
\hline $\begin{array}{l}\text { Calicinal base diameter for adult and } \\
\text { subadult corallites not truncated by } \\
\text { Hicetes; radial lenght and width }\end{array}$ & $\begin{array}{c}6.6 \times 3.3 \\
(8 \text { measur. })\end{array}$ & & & $\begin{array}{c}6.8 \times 3.7 \\
(3 \text { measur. })\end{array}$ & \\
\hline Thickness of the wall & $0.4-0.5$ & & & 0.45 & \\
\hline Mural pore diameter & $0.25-0.45$ & $0.20-0.35$ & & $0.17-0.28$ & \\
\hline Hicetes gallery diameter & $2.8-3.9$ & $2.2-2.5$ & & $1.9-2.4$ & $2.9-3.0$ \\
\hline
\end{tabular}


Figure 2. Procteria (Granulidictyum) alechinskyi sp. nov., lower part of the Floresta Formation, Quebrada Monticelo section, upper Emsian. Drawings of specimens in natural casts; A - diagrammatic drawing of a subadult corallite showing, on left the outline of the so called lanceolate axial structure (hatched area) and, on right, a vertical transverse section in the calicinal base; B, C - specimen LPB 16714 (holotype), calicinal bases of eucorallites showing rather numerous prints left by the spines and the casts of the septal ridges on the peripheral margin of subadult corallites (black circle as major septal ridges, black triangle as ?cardinal ridge, open circle as minor ridges); $\mathrm{D}$ - specimen LPB 16715 , note two well exposed small interstitial corallites on top of the Figure.
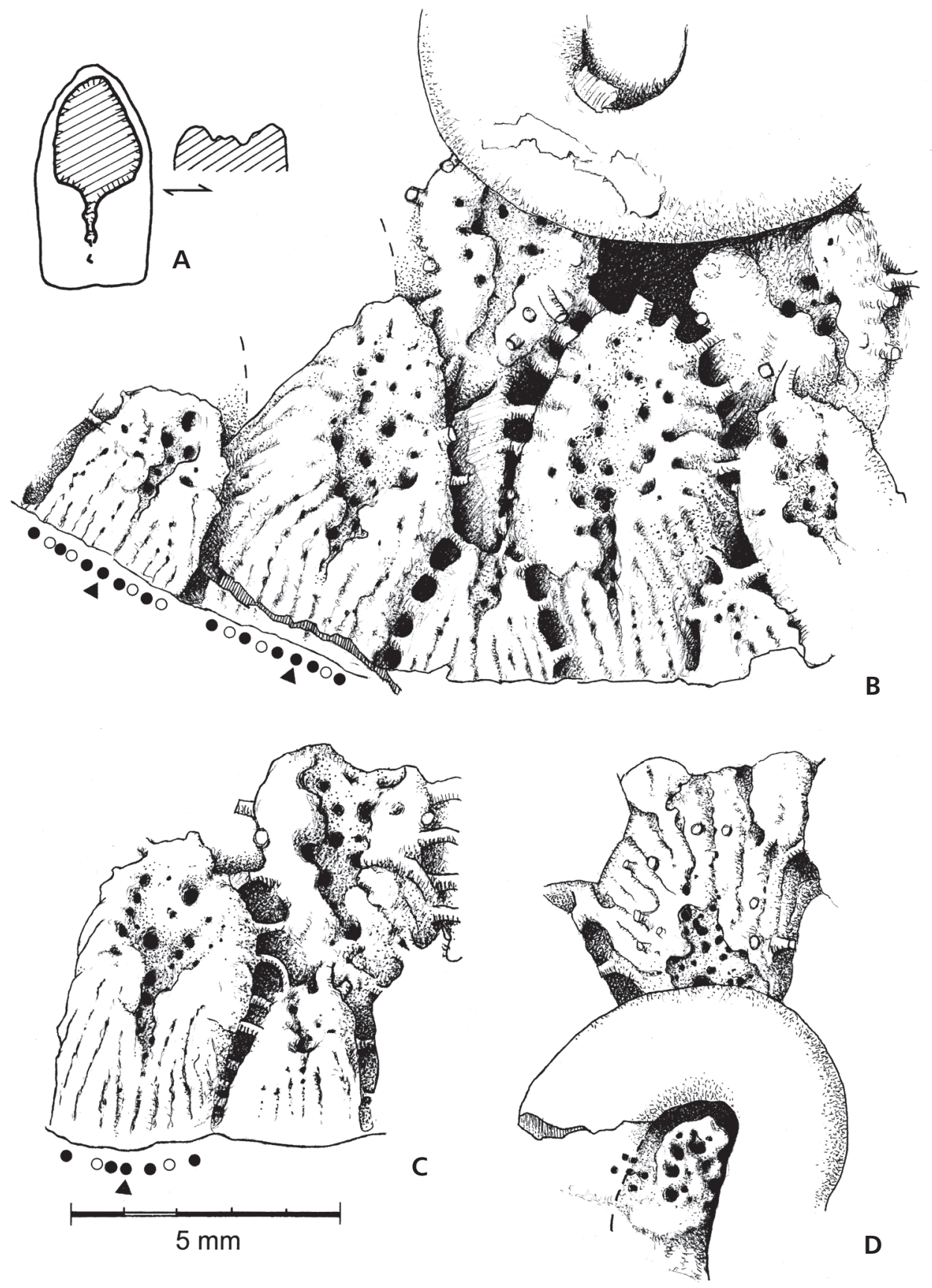

Thuringia, Steinach Formation, Member B, has been discussed by Plusquellec et al. (2013, pp. 200, 202). From unpublished data it can be stated that this species is characterized by a medium sized corallum ( $c a .15-17$ $\mathrm{mm}$ ), a number of corallites not exceeding (?)21, the lack of interstitial corallites, moderately numerous basal plate pores and an axial structure of the calicinal base generally narrow and sinuous either appearing in natural mould as a single row of prints of spines (Weissermel 1941a, pl. 5, fig. 15) or as a deep depression similar to that of $P$. (G.) elisabetae although generally narrower.
Procteria (G.) cornu from the Lower Givetian of Eastern North America and $P$. (G.) granuliferum from the upper Eifelian of the Eifel are medium to large sized species with numerous eucorallites. The morphology of the calicinal bases of G. cornu is not known, or poorly known, owing to the kind of preservation (calcitic skeleton instead of natural mould which is the best preservation to see the calicinal bases morphology). According to Stumm (1950, diagnosis of his new species) bases of corallites are flat; the vertical section given by Stumm (1950, pl. 5, fig. 12) could confirm this statement and shows that 
the presence of a potential strong axial structure can be excluded. Later, Stumm (1967) indicated that the holotype has been cleaned but does not give more data about the calicinal bases morphology.

In $P$. (G.) granuliferum, the section illustrated by Schlüter (1889, pl.4, fig. 7) - and later studied by the author of the present paper - as well as a section taken in a specimen from Belgium (Plusquellec 2007, fig. 6a) does not show obvious axial structure. Unfortunately the species of Schlüter has never been studied on the basis of specimens from the type area and preserved in natural mould; thus this very "common species" is in fact not well known!

In addition, in the two species, the calicinal morphology on the upper surface of the corallum is roughly similar except for the presence of sharp spines at the junction of corallites said to be diagnostic of $P$. (G.) cornu and its lower number of interstitial corallites.

In the specimens from the Armorican Massif, preserved in natural mould and assigned to $P$. (G.) granuliferum (see a typical example in Plusquellec 2007, pl. 3, fig. 8), the calicinal bases are flat and the axial structure consists of a single row of pits left by septal spines or less usually in the mould of a very narrow ridge. These discrete radial structures are, of course, hardly visible in vertical section ( $c f$. above, comment on the section in the type material of Schlüter) and thus the assignment of the Armorican specimens to granuliferum is questionable and the assignment to $(G$.) e.g. granuliferum would probably be better.

The so called $P$. (G.) granuliferum morphotype "Bolast" (Plusquellec 2007, pl. 3, fig. 7) from the uppermost Emsian of the western Armorican Massif, Bolast Formation, is very likely a new species, the diagnosis of which could be as follow: corallum moderately concavo-convex, medium to large sized, usually about $23 \mathrm{~mm}$ in diameter with 40-42 regularly polygonal (especially the protocorallite) to rhombic eucorallites; interstitial corallites numerous. Axial structure of the eucorallites appearing in natural cast as a deep, wide and rounded depression occupying $1 / 2$ to $2 / 3$ of the calicinal base in the central area of the colony, becoming more and more elongated, even rather narrow, toward the periphery, and bearing moulds of few well marked scattered spines. The calicinal surface of the corallum is less convex than in G. granuliferum (type material) and G. e.g. granuliferum from the Armorican Massif.

Among these species, it is with the so called $P$. (G.) granuliferum morphotype "Bolast" that the Columbian material share most characters: size of corallum, number of eucorallites, presence of numerous interstitial corallites, small diameter of basal plate pores and overall calicinal bases with a well-developed axial structure. However, the Columbian representatives can easily be distinguished from the Armorican ones by some features of their axial structure which is wider in its initial and median area in the central part of the corallum as well as in its margins, which shows a more or less lanceolate outline at the calicinal base level, whose morphology remains the same from center to margin of the colony and which bears generally more numerous and stronger spines.

The presence of Hicetes is by no means diagnostic.

Thus the specimens from the Floresta Formation are clearly distinct from all previously described Granulidictyum and belong to a new species mainly characterized by the Pleurodictyum-like morphology of their calicinal bases.

The new species herein described is only known in the Quebrada Monticelo section but is close to undescribed specimens (LPB 16 719-721) from the lower Member of the Herrera Formation, lower Emsian of Chillón, Almadén Syncline, Central Iberian Zone (Spain). This material assigned to $P$. (Granulidictyum) sp. e.g. alechinskyi and illustrated here for comparison (Fig. 1F, G) shows that the Pleurodictyum-like morphology of the calicinal bases in the sub-genus is not a rarity. This feature is known in two areas of the north and western margin of the Gondwana, respectively in Spain and Columbia, as well as in two stratigraphical levels, lower Emsian (Spain) and upper Emsian (Columbia). Note that the Spanish colonies are devoid of Hicetes.

Conclusion about Granulidictyum: Three groups of forms can be distinguished within the sub-genus Granulidictyum: 1) small forms with few eucorallites, flat calicinal base without axial structure, numerous and large basal plate pores, interstitial corallites lacking: ?G. gavaensis, G. simplex; 2) medium to large sized forms, eucorallites rather numerous to numerous, calicinal bases flat without axial structure or generally bearing a more or less strong, narrow axial/radial structure, interstitial corallites present, basal plate pores common and small: G. granuliferum and e.g. granuliferum, G. cornu, G. "richteri", G. elisabetae; and 3) medium to large sized forms, eucorallites rather numerous to numerous, wide and well-marked convex Pleurodictyum-like axial structure occupying the calicinal bases, interstitial corallites present, frequency of basal plate pores variable and small: G. granuliferum morphotype "Bolast", G. alechinskyi and G. sp. e.g. alechinskyi.

The known stratigraphic distribution of Granulidictyum which is common from lower Emsian to upper Givetian, is not modified by its presence in the late Emsian of Columbia but it brings new data about the occurrence of the Procteria/Hicetes system formerly known only in P. (Pachyprocteria) vermifera Plusquellec, Desbiens \& Gourvennec, 2011, in the lower Eifelian of the Gaspé Sandstones in Québec (Canada). 
Genus Amazonodictyum Plusquellec, 2007

Type species. - Pleurodictyum amazonicum Katzer, 1903.

\section{Amazonodictyum amazonicum (Katzer, 1903)}

1903 Pleurodictyum amazonicum Katzer; Katzer, p. 268, pl. 9 , fig. 1.

1965 Pleurodictyum americanum Roemer 1876. - Morales, pp. 76, 77, pl. 1, fig. 1.

1913 Pleurodictyum amazonicum Katzer. - Clarke, p. 79 (not described).

1923 Pleurodictyum amazonicum Katzer. - Kozlowski, pp. 97, 98, pl. 10, figs 1, 2.

1925 Pleurodictyum amazonicum Katzer. - Swartz, p. 39 (not described).

2007 Amazonodictyum amazonicum. - Plusquellec, fig. 40.

Remarks. - This species was not collected by Racheboeuf but one of the specimens from Floresta, illustrated by Morales (1965, pl. 1, fig. 1), and assigned to Pleurodictyum americanum Roemer, 1876, seems to be similar to the specimens of Amazonodictyum amazonicum common in Bolivia, in the Belen Formation, likely upper Emsian (or lowermost Eifelian?); see a convincing Bolivian specimen from Chiarumani illustrated by Plusquellec (2007, pl. 4, fig. 5).

The others specimens studied by Morales are either doubtful (1965, pl. 1, fig. 2) or clearly different (pl. 1, fig. 3).

Family Favositidae Dana, 1846

Subfamily Paleofavositinae Sokolov, 1950

\section{Genus Paleofavosites Twenhofel, 1914}

Type species. - Favosites aspera [sic!] d'Orbigny, 1850.

\section{Paleofavosites sp.}

Figure 3

1965 Favosites sp. aff. F. hamiltoniae Hall 1876. - Morales, p. 77 , pl. 1, figs 4,5 .

Material. - One specimen, LPB 16 722, from Quebrada Monticelo section, Floresta Formation (late Emsian). The material consists of 6 offcuts, 4 thin sections, 2 ultra-thin sections and 4 acetate peels.

Description. - The specimen is a part of a massive corallum, partly silicified, probably with a so-called epitheca (inferred from thin section, Fig. 3A), with polygonal corallites in cross section, $6-7$, even 8 sided in adult stage. Mean corallite diameter of this category is $2.95 \mathrm{~mm}$ and ranges from $2.5-3.4 \mathrm{~mm}$. Corallite walls are thin, straight or somewhat sinuous (Fig. 3B), usually $0.08-0.20 \mathrm{~mm}$ thick.

Contrary to what Morales stated, pores are present. Pores of the wall pore variety (sensu Powell \& Scrutton $1978,=\mathrm{P}_{2}$ sensu Plusquellec 1976) are identified in transverse sections; they are located in the middle part of the wall but more frequently in lateral position suggesting two rows; some may have a raised rim (Fig. 3E). Angle pores $(\mathrm{P} 1)$ are recorded but are clearly less numerous than $\mathrm{P}_{2}$ (Fig. 3E, F). Mural pores may be sealed by a pore plate generally shifted on one side of the wall, indicating that it was produced by one of the two adjacent polyps as shown by Plusquellec et al. (2012, fig. 2).

Septal spines are variably developed from corallite to corallite; when present they are generally slender and long projecting in some case almost to axis. Scarce squamulae are identified on transverse sections, some of them appearing bifid (Fig. 3C, D).

The tabulae are thin and numerous, horizontal, flat, slightly to moderately, even strongly concave or slightly convex. Tabular spacing varies from $0.4-1.5 \mathrm{~mm}$, mean $0.83 \mathrm{~mm}$.

Microstructure: Study of the microstructure of the wall by the use of polished ultra-thin sections (the socalled "LFP" in French) allows observations that cannot be provided by sections of $30 \mu \mathrm{m}$ thick.

Despite rather poor preservation, the longitudinal LFP sections show - on both sides of a median lamina which roughly consists of granules and/or plaquettes - a layer of stereoplasm made of microlamellae (Fig. 3G). They are clearly curved, rather thick and cupulate as usual for this kind of biocrystal. Dimensions of the microlamellae: length about 30-40 $\mu \mathrm{m}$, thickness 8-10 $\mu \mathrm{m}$.

Discussion. - Generic and specific assignment: Lafuste \& Tourneur (1988) have shown the microlamellar microstructure of the wall of the Silurian favositids: Favosites (F. gotlandicus Lamarck, 1816 - type species of the genus Favosites) and Paleofavosites/Mesofavosites. The authors also underlined the fibrous nature of the wall of Devonian representatives and indicate that these "Favosites" will be assigned to another genus. Later, Plusquellec \& Tourneur (1998) pointed out the persistence of microlamellar favositids in the Lower Devonian of Algeria and Turkey.

Owing to the presence of microlamellae, and of both wall pores and angle pores our material can be assigned to Paleofavosites.

Only a very few Devonian microlamellar favositids are known, and thus a reliable specific assignment remains illusive. Moreover the variability of the Columbian Paleofavosites is unknown.

Let us indicate nevertheless that the corallite diameter of our specimen is close to that of Paleofavosites 
saourensis (Le Maître, 1952), uppermost Emsian, but the morphology and size of the corallum is quite different and the spines are clearly longer. Moreover the median lamina does not show the elongated fiber-like units described in the Algerian species.

As for the "Favosites" bohemicus mosellanus Weissermel, 1941b (lowermost Eifelian) or "Favosites" bohemicus grandis Le Maître, 1952 (uppermost Emsian) they are characterized by large to very large corallites.

Lastly, the comparison with Favosites hamiltoniae Hall, 1876 cannot be supported because its microstructure is unknown and this species is said (original description) to be "without septal ridges or spines on the specimens examined".

The presence of microlamellar favositids in the Lower Devonian of Columbia indicates: 1) that the persistence of this microstructure in the Devonian favositids is probably not so unusual as alleged; and 2) that the identification of the favositid genera definitely needs the knowledge of the wall microstructure.

Subclass Rugosa Milne-Edwards \& Haime, 1850

Order Stauriida Verill, 1865

Family Devonodiscidae Pedder, 2019

Remarks. - According to Pedder (2019) the main characteristics of this new family of solitary Rugosa with Devonodiscus as type-species - are: 1) corallum discoid (at least in early stages); 2) corallum epithecate; 3) horizontal elements (dissepiments) absent from some species; 4) minor septa may or may not be contratingent; 5) septal microstructure trabeculate (likely monacanthine); and 6) adjacent septa contiguous for much of their length in discoid part of corallum (= septothecal wall). The presence of some lamellar tissue remains questionable.

This diagnosis fits rather well with that of the Palaeocyclidae as defined by Hill (1981), except for the presence of trochoid forms in this latter family, and fits too with that of the genus Palaeocyclus, particularly with regard to the points 5 and 6 . In addition, it can be noted that some Canadian Devonodiscus were previously assigned to Palaeocyclus ... (see synonymy of D. multiradiatus in Pedder 2019).

Unpublished data about the microstructure of some Palaeocyclidae (Plusquellec, work in progress based on the use of ultra-thin sections), such as Palaeocyclus porpita (Linnaeus, 1767) from the Llandovery of Gotland and Rhabdocyclus porpitoides (Lang \& Smith, 1927) from the late Wenlock of Dudley support Pedder's assignment of Devonodiscus to a new family.

Hill (1936) stated that the microstructure of each septum of P. porpita consists of contiguous monacanthine trabeculae, whereas in $R$. porpitoides it consists of rhabdacanths "bound into a plate by lamellar sclerenchyme" (Hill 1936, p. 198).

With regard to $R$. porpitoides we agree with Hill's observations. The septa are clearly rhabdacanthine and the interseptal area between major and minor made of lamellar sclerenchyme.

About $P$. porpita we believe Hill misinterpreted the data because sections of usual thickness are very confused and that the septa are not monacanthine. Transverse ultrathin sections (the so-called "LFP") show that the septa consist of bundle of rods $(\varnothing \mathrm{ca} .30 \mu \mathrm{m})$ bound into a plate by abundant and more or less distinct tiny lamellae, that is to say rhabdacanths. It should also be noted that Hill (1936, p. 195) writes "frequently there is a suggestion that the trabecula includes a number of rod-like aggregates of fibers". Quid erat demontrandum, it seems in fact that Hill has seen the rhabdacanths! In addition, the welldeveloped interseptal sclerenchyme (not recorded by Hill) shows excessively small lamellae (about 14-17 $\mu \mathrm{m} \times$ 2-3 $\mu \mathrm{m})$. Thus the septal microstructure of $P$. porpita and R. porpitoides is similar, i.e. rhabdacanthine.

In addition, it can be noted that McLean \& Copper (2013), dealing with Rhabdocyclus stated that "the septal microstructure is regarded to be of greater significance" and it appears here that 'septa with rhabdacanthine microstructure' must be added in the diagnosis of the family Palaeocyclidae.

In $P$. porpita and $R$. porpitoides the interseptal sclerenchyme is rather well developed and is more or less in microstructural continuity with the septa. As a result, the wall is not a septotheca but belongs to another category consisting of a lamellar palisade interrupted by the septa or in which the septa are wedged. This wall structure recalls the "muraille lamellaire" of Semenoff-Tian-Chansky (1987, fig. 421a).

On the other hand, thanks to A. Pedder who gave to the author specimens of Devonodiscus latisubex while his paper was in press, it has been possible to prepare "LFP" sections of the species. These "LFP" provide some new data about the microstructure of the septa and dissepiments (a joint paper with Alan Pedder is in progress) and show: 1) The material has undergone weak diagenesis and is in fact moderately to rather well preserved; nevertheless, owing to the small size of the biocrystals, the $30 \mu \mathrm{m}$ thin sections are somewhat blurred. 2) The trabeculae forming the septa are clearly fibrous, not holacanthine or monacanthine but water-jet with a moderate angle between the most external fibers of the fibrous fascicles [distinction between waterjet trabeculae and other trabecular microstructure are well illustrated by Cuif \& Gautret, 1993]. 3) The trabeculae are surrounded by a more or less thick tissue apparently made of small elements recalling the microlamellae. The "structureless calcite presumed to be recrystallized lamellar tissue" described 

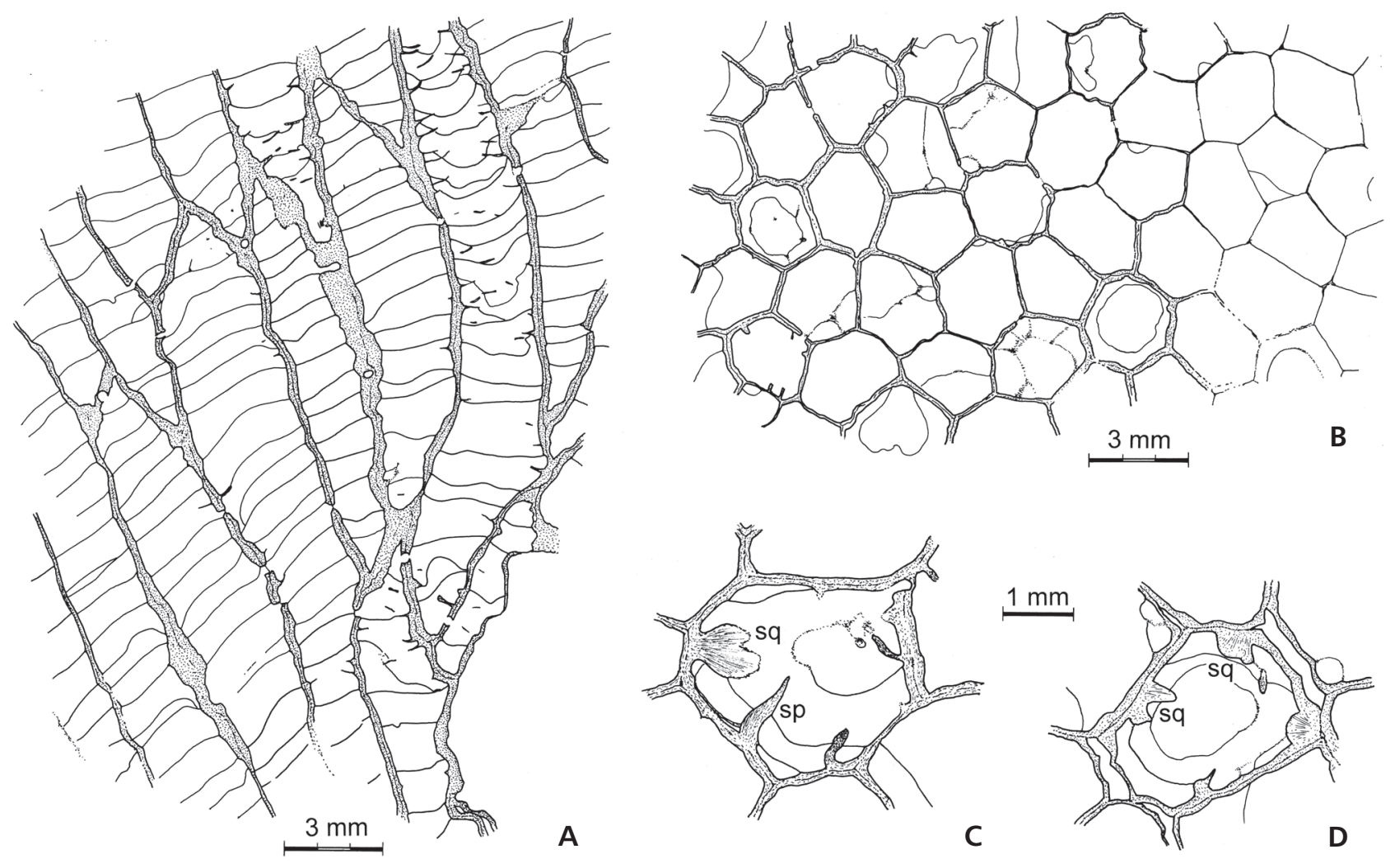

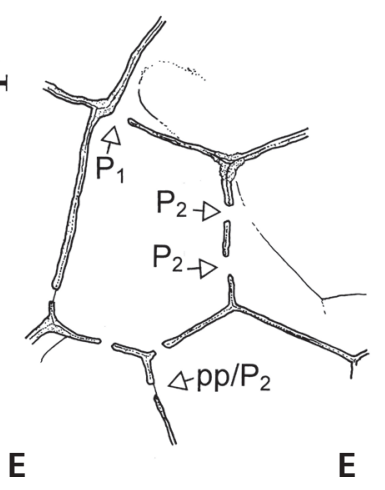

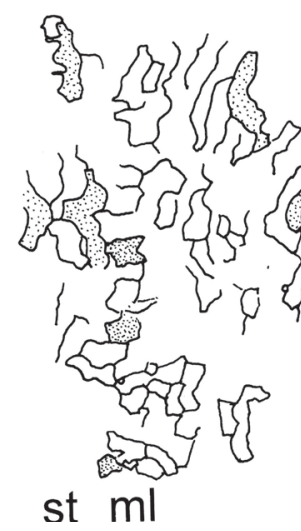

st $\mathrm{ml}$

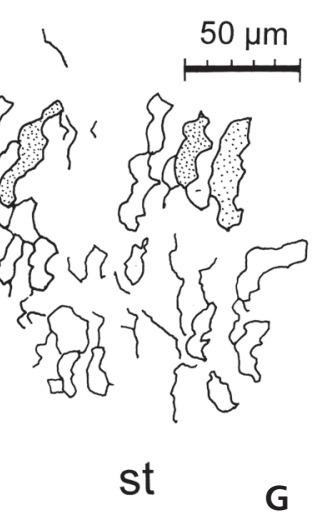

Figure 3. Paleofavosites sp. lower part of the Floresta Formation, Quebrada Monticelo section, late Emsian. Specimen LPB 16722 ; A - longitudinal thin section $\mathrm{Bb} 716$, note the section of the so-called epitheca (lower left) and the well-developed septal spines (upper right); B - transverse thin section BR 2478 showing important change in the thickness of the wall; C, D - close up of two corallites in transverse section showing the presence of squamulae (sq) and spines (sp); respectively thin section Bb 715 and BR 2479; E, F - corallites in transverse section showing the two categories of mural pores, angle pores $\left(\mathrm{P}_{1}\right)$ and wall pore $\left(\mathrm{P}_{2}\right)$; respectively thin section BR 2478 and acetate peel "B"; $\mathrm{G}$ - microstructure in longitudinal section showing the median lamina (lm) and the microlamellar stereoplasm (st), "LFP" BR 2122.

by Pedder $(2019$, p. 148$)$ could be the same structure. 4) In fact, the microstructural units forming the septa are composite, made of a core of water-jet trabeculae coated by a microlamellar sclerenchyme. 5) The dissepiments show well preserved and very characteristic microlamellae (size and morphology).

Hence, the microstructure of the Devonodiscidae is distinct from that of the Palaeocyclidae by its type of trabeculae (water-jet $v s$ rhabdacanths) and by the wall structure (septothecal vs "lamellar"). The usual presence of a long and narrow cardinal fossula emphasizes the difference between the two families. However, these two families share an unusual feature i.e. the presence of lamellar/microlamellar tissue surrounding on one hand the rods of the rhabdacanths and in the other hand the waterjet trabeculae. 
Genus Devonodiscus Pedder, 2019

Type species. - Devonodiscus latisubex Pedder, 2019.

\section{Devonodiscus pedderi sp. nov.}

Figures 4, 5

Holotype. - LPB 16712.

Type horizon and locality. - Lower part of the Floresta Formation, upper Emsian. Quebrada Monticelo section, $\mathrm{N}-\mathrm{W}$ of Tobasia, Columbia.

Material. - Two specimens preserved in natural moulds of which one only known by its proximal side, LPB 16712-713. Quebrada Monticelo section, Floresta Formation, bed 5, (upper Emsian).

Etymology. - Species dedicated to our colleague Alan Pedder, the "father" of the genus Devonodiscus.

Description. - Latex moulds of this discoid solitary coral have been made. These are the basis of the following description.

Proximal side (lower surface): This side is slightly elliptical in plan view, flat, except at its margin which shows a trend to be geniculate (Fig. 4A), and is covered with well-defined eccentric growth rings: the socalled epitheca (Fig. 5E). The best preserved specimen bears a small eccentrically placed cone of attachment, strongly obliquely directed and shifted toward the counter area (Figs 4C; 5E, F). This cone corresponds to an unusually developed (or preserved?) first stage of growth in discoid corals very similar to that illustrated in the Silurian Palaeocyclidae Rhabdocyclus porpitoides by Lang \& Smith (1927, fig. 16).

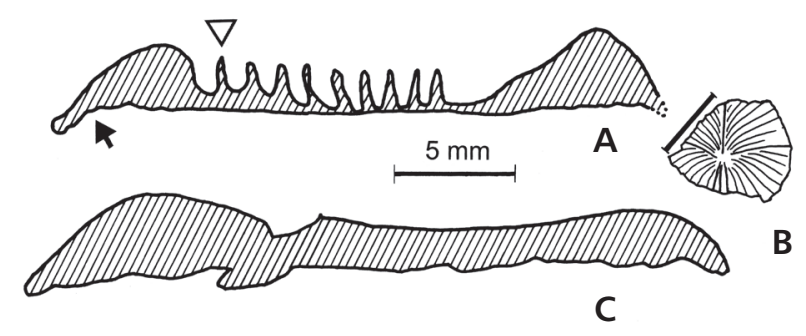

Figure 4. Devonodiscus pedderi sp. nov., lower part of the Floresta Formation, Quebrada Monticelo section, late Emsian. Specimen LPB 16712 (holotype); A - eccentric vertical section in the natural mould before splitting the two sides; toward the cardinal septum on right, alar on left (likely the septum indicated by open triangle), black arrow points out the location of the peripheral geniculation. It can be noticed that the skeleton is very thin between the septa; B - schematic drawing of the distal side of the natural mould (see also Fig. 4B) showing the location of the section illustrated in $\mathrm{A} ; \mathrm{C}$ - tentative axial section of the corallum along $\mathrm{C}$ (on right) $\mathrm{K}$ (on left).
Distal side (upper surface), preliminary remarks: In a recent paper Wang et al. (2015) propose abandoning the use of the term counter lateral septum, thus reducing the number of protosepta from six to four. I disagree with this interpretation because:

1) The structure of the K-KL sector is somewhat distinctive, the pair of minor septa being not always ( see Wang et al. 2015, fig. 3i), but often longer (see Microcyclus discus Meek \& Worthen, 1868 and M. thedfordensis Bassler, 1937, in Stauffer 1952, respectively pl. 1, fig. 3 and pl. 2, figs 10,19) or even absent in cystiphyllids (Birenheide 1974).

2) In some cases only six septa $(C, K, A, K L)$ are well developed (see Hexalasma illustrated by Weyer 2014, fig. 12).

3) In Combophyllum osismorum Milne-Edwards \& Haime, 1850, a transverse section (Plusquellec \& Semenoff-Tian-Chansky 1972, fig. 9) clearly shows an "early stage" with six septa and a pattern of splitting of the counter lateral and alar protosepta absolutely similar and thus, it seems obvious that these septa are homologous. The cardinal and counter septum define the plane of bilateral symmetry whereas the counter lateral and the alar produce symmetrically the first metaseptum in each sector.

4) If the counter lateral septa are not accepted as protosepta, then the counter and the alar are not homologous, the metasepta being produced on both sides of the former and on one side of the latter.

5) How the minor two septa on both sides of the counter septum have arisen is not known (Weyer personal communication 2017) contrary to suggestions of Wang et al. (2015, p. 392) and thus their argument in favor of four protosepta cannot be taken into account.

6) As it has been established that the Palaeozoic and post-Palaeozoic corals are monophyletic (Cuif 1977) it is interesting to point out the persistence of early stage of growth with a bilateral symmetry and six protosepta and to underline the similarities between sections in Combophyllum osismorum (Plusquellec \& SemenoffTian-Chansky 1972, pl. 4, fig. 2b) and Ceratocyathus cf. zanclaeus (Cuif 1968, pl. 4, fig. 4).

The everted calice shows a shallow depressed center, a well-marked bilateral symmetry and an obvious pinnate pattern of the septa emphasized by the development of the fossulae.

The cardinal septum, as well as the alar septa, clearly reach the axis of the corallum whereas only the right counter-lateral protoseptum shows this feature. The cardinal septum, long and narrow, is lower in height to flanking major septa especially for the peripheral half of its length. The alar septa and the counter-lateral are similar in height and thickness to the metasepta whereas the counter septum appears distinctly thinner and, although 

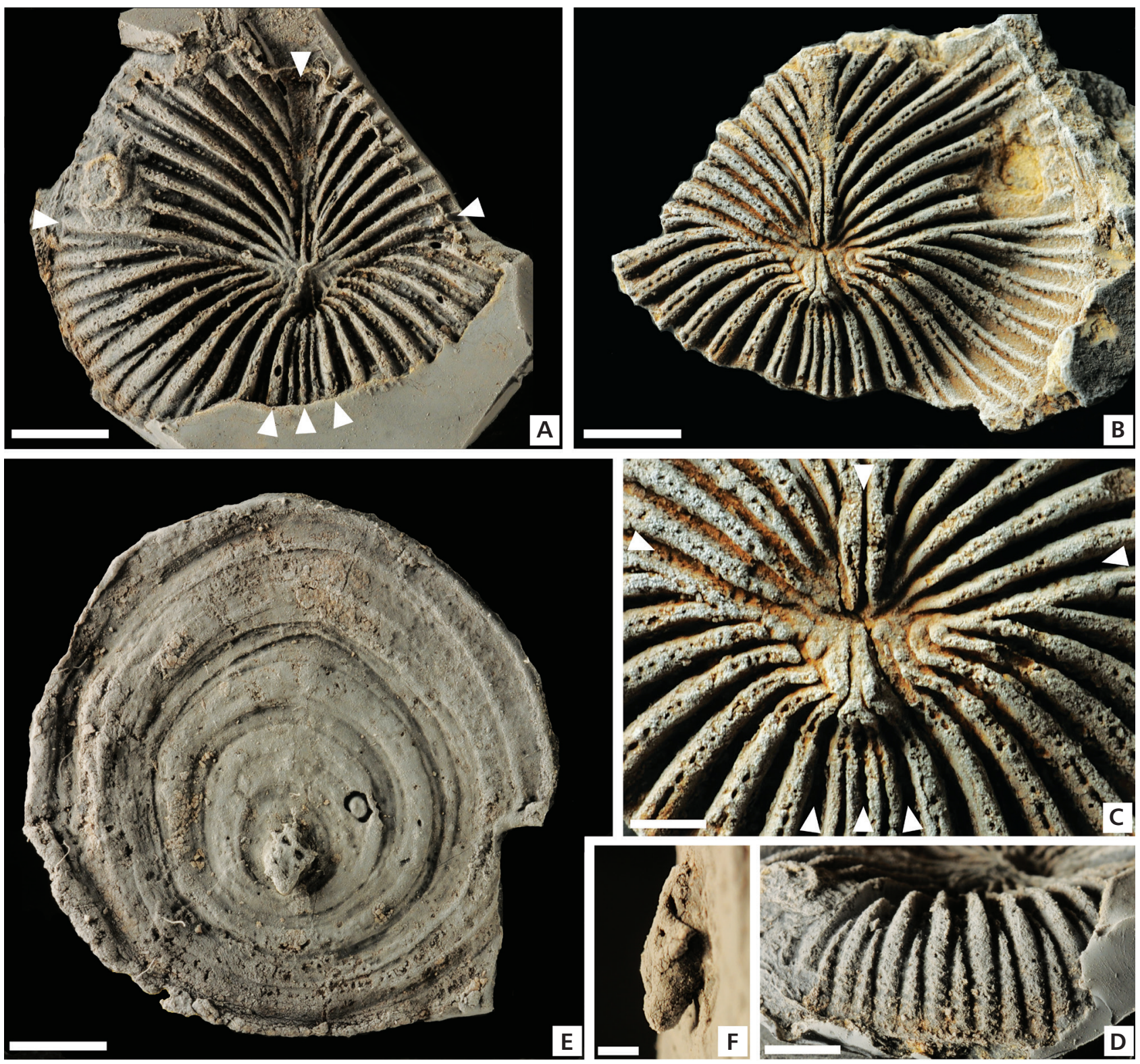

Figure 5. Devonodiscus pedderi sp. nov., lower part of the Floresta Formation, Quebrada Monticelo section, upper Emsian. Specimen LPB 16712 (holotype); A - latex cast of the distal side, triangles indicate the location of the protosepta; B - natural cast of the distal side; $\mathrm{C}$ - idem, magnification of the central area of the corallum. Note the single row of pits left by the spines on the minor septa; D - oblique side view of the latex cast (left counter-lateral sector); E - latex cast of the proximal side; F - side view of the "cone of attachment". In A, B, C and E the cardinal septum is at the top. Magnification: A, B, E scale bar $=5 \mathrm{~mm} ; \mathrm{C}$ scale $\mathrm{bar}=2 \mathrm{~mm}$; D scale bar $=3 \mathrm{~mm} ; \mathrm{F}$ scale bar $=1 \mathrm{~mm}$.

partly preserved, its morphology is closer to that of the cardinal septum than of the alar ones (Fig. 5A-C).

The cardinal fossula is well-marked, closed, very narrow and parallel sided; the alar fossulae are very narrow and their location mainly highlighted by the pinnate arrangement of the metasepta (Fig. 5A).

The major metasepta extend near to the center of the corallum, are rather thick especially for the outer half of their length, smooth, except in their very peripheral part where a discrete crenulation can be seen (Fig. 5D).
The outer ends of the minor septa (= catasepta sensu Wang et al. 2015) in the counter-lateral sector have a more or less serrate margin (Fig. 5D), whereas their inner parts consist of a single row of spines (Fig. 5A, C) probably formed by the end of the monacanthine trabeculae described by Pedder (2019) in Devonodiscus latisubex and D. multiradiatus. In addition, it can be noted 1) that the peripheral part of the minor septa in the counter-lateral sector is distinctly thicker than in the alar one, 2) that the pair of minor septa on both sides of the counter septum 
(counter sector) is less spinose and higher than the other minor septa and 3) that in each sector the minor septa are not contratingent and this feature is particularly obvious on the natural mould (Fig. 5C).

Measurements: Corallum diameter along $\mathrm{C}-\mathrm{K}$ ca. $29 \mathrm{~mm}$, along A-A ca. $27 \mathrm{~mm}$. Number of septa: Protosepta $=6$. Major septa in the left alar sector, exposed $=8$, estimated $\geq 9 ;$ minor septa exposed $=9$, estimated $\geq 9$. Major septa in the right alar sector, exposed $=8$, estimated $\geq 9$; minor septa exposed $=9$, estimated $\geq 9$. Major septa in the left counter-lateral sector $=9$; minor septa $=8$. Major septa in the right counter-lateral sector, exposed $=7$, estimated $\geq 8$; minor septa exposed $=8$, estimated $\geq 8$. Minor septa in the left and right counter sector $=1$. Total number of septa, estimated $\geq 77$.

Generic and specific assignment: The material from Columbia shows all the outstanding features of Devonodiscus as defined by Pedder (2019) and the closest species is D. multiradiatus (Meek, 1868).

Our specimen is markedly distinguished from D. multiradiatus by the following characteristics: central smooth area is much smaller; cardinal fossula does not show a rhopaloid trend and is more distinct; pinnate arrangement of the metasepta is much more pronounced; structure of the K-KL sector appears different, especially by the presence of a pair of minor septa which seems to be missing in D. multiradiatus (see particularly Pedder 2019, fig. 7a); counter septum is markedly distinguishable from the counter-lateral; the minor septa are not contratingent and over all clearly spinose; at equal diameter the septa are less numerous.

The Columbian specimen cannot be confused with ?D. clebroseptatus (Kravtsov in Besprozvannykh et al. 1975) owing to the presence of a prominent calicular boss, the small difference in thickness of the major and minor metasepta at the calicular margin and its total number of septa about 114 (estimated from Kravtsov 1975, pl. 21, fig. 2a, holotype).

Thus, our material clearly belongs to a new species, which, despite its limited material, is erected herein and named Devonodiscus pedderi.

The stratigraphic distribution of the genus Devonodiscus which occurs from the upper Lochkovian or lower Pragian of south Taimyr in Russia (?D. clebroseptatus seems to be the oldest known possible species of the genus) to the upper Eifelian of the District of Mackenzie in Canada (D. multiradiatus) is completed by its presence in the upper Emsian of the Cordillera oriental of Columbia (Devonodiscus pedderi).

The genus has a wide palaeogeographic distribution, and the localities yielding representatives of Devonodiscus belong to South Siberia (?D. clebroseptatus), North West Laurussia (D. multiradiatus) and Western Gondwana (D. pedderi). Therefore, according to Oliver (1977, fig. 1)
Devonodiscus is known on both sides of the equator, in the northern and western area of the Old World Realm and in the western part of the Eastern Americas realm.

\section{Conclusions}

Detailed conclusions are provided at the end of each paleontological section, however we can stress that the most interesting forms were not previously described by Morales (1965). The studied material allows description of 1) a new species of Granulidictyum and a new category of this subgenus characterized by Pleurodictyum-like calicinal bases, 2) a microlamellar favositid assigned to Paleofavosites sp., and 3) a new species of Devonodiscus. The genus Devonodiscus seems to be rather uncommon in South America whereas it is abundant in northwestern Canada. Devonodiscus is distributed in three distinct areas and in three levels of the lower and middle Devonian. Lastly, Pleurodictyum americanum sensu Morales, 1965 is reassigned to Amazonodictyum amazonicum and thus, the genus Pleurodictyum is, as far as I know, not recorded in Columbia.

\section{Acknowledgements}

The specimens were obtained for study by courtesy of P. Racheboeuf; P. Morzadec as well as P. Racheboeuf provided information about the material and the stratigraphy of the Floresta Formation and R. Gourvennec helped with the photographs and Photoshop (C) matters. Thanks to A. Pedder for making available unpublished data on his new genus Devonodiscus and for giving me nice specimens of D. latisubex, and to M.V. Pardo Alonso for stratigraphic information about the Chillón locality. Special thanks to A.J. Wright for the linguistic review of this paper as well as for relevant scientific comments and to the reviewers Ross McLean and Alan Pedder for valuable suggestions and other items that helped to improve the manuscript.

\section{References}

Bassler, R.S. 1937. The Paleozoic rugose coral family Paleocyclidae. Journal of Paleontology 11, 189-201.

Besprozvannykh, N.I., Dubatolov, V.N., Kravtsov, A.G., Latypov, Yu.Ya. \& Spassky, N.YA. 1975. Devonian Rugosa of Taimyr-Kolymian Province. Akademiya Nauk SSSR, Sibirskoe Otdelenie, Trudy Instituta Geologii i Geofiziki 228, 1-172. [in Russian]

Birenheide, R. 1974. Zur Herkunft der devonischen cystimorphen Rugosa. Senckenbergiana Lethaea, 54, 453-473.

CAster, K.E. 1939. A Devonian fauna from Columbia. Bulletins of American Paleontology 24(83), 1-218.

Clarke, J.M. 1913. Fósseis Devonianos do Paraná. Monographias do Servico Geológico e Mineralógico do Brasil, 1, 1-353. DOI 10.5962/bhl.title.146614 
DANA, J.D. 1846. Structure and classification of zoophytes: narrative of the U.S. exploring expedition during the years 1838, 1839, 1840, 1841, 1842 under the command of Charles Wikes, U.S.N., Vol. 7. 740 pp. GP Putnam, Philadelphia.

Davis W.J. 1887. Kentucky Fossil Corals - a Monograph of the Fossil Corals of the Silurian and Devonian Rocks of Kentucky, Part II. 1-4 + i-xiii. Kentucky Geological Survey.

Clarke, J.M. 1908. The Beginning of Dependant Life. New York Museum Annual Report 61, Museum Bulletin 121, 147-169.

CuIF, J.-P. 1968. Etude ontogénique de quelques madréporaires Caryophyllidae actuels et fossils. Mémoires du Muséum national d'Histoire naturelle C 16(3), 101-156.

CuIf, J.-P. 1977. Arguments pour une relation phylétique entre les madréporaires paléozoïques et ceux du Trias. Mémoires de la Société géologique de France 129, 1-51.

Cuif, J.-P. \& Gautret, P. 1993. Microstructural features of fibrous tissues in the skeletons of some chaetetid sponges. Courier Forschungsinstitut Senckenberg 164, 309-315.

Davis, W.J. 1887. Kentucky Fossil Corals - a monograph of the Fossil Corals of the Silurian and Devonian Rocks of Kentucky, Part 2. Kentucky Geological Survey 1985, 1-13.

Forero SuÁrez, A. 1991. El Paleozoico superior del flanco oriental de la Cordillera Central. Geología Columbiana 7 , 139-145.

Fuchs, G. \& Plusquellec, Y. 1982. Pleurodictyum problematicum Goldfuss 1829 (Tabulata, Dévonien) Statut, Morphologie, Ontogénie). Geologica et Paleontologica 15, 1-26.

Goldfuss, G.A. 1829. Petrefacta Germaniae, Abbildung und Beschreibung der Petrefacten Deutschlands und angrenzender Länder. Band 1, Lieferung 2. 77-164 pp. Arnz, Düsseldorf.

Hall, J. 1876. Illustrations of Devonian fossils, Gasteropoda, Pteropoda, Cephalopoda, Crustacea and Corals of the Upper Helderberg, Hamilton and Chemung Groups, III. Geological Survey of the State of New York, Palceontology, $39 \mathrm{pls}+7 \mathrm{pp}$.

Hill, D. 1936. The British Silurian Rugose Corals with Acanthine Septa. Philosophical Transactions of the Royal Society of London, series B-Biological Sciences, $n^{\circ} 534$, vol. 226, 189-217. DOI 10.1098/rstb.1936.0007

HiLl, D. 1981. Cœelenterata, part F, supplement 1, Rugosa and Tabulata, F1-F378 (v. 1), F379-F762 (v. 2). In Teichert, C. (ed.) Treatise on InvertebratePaleontology. Geological Society of America \& University of Kansas Press, Lawrence.

Johnson, J.G. \& KLAPPER, G. 1992. North American midcontinent Devonian T-R cycles. Oklahoma Geological Survey, Bulletin 145, 127-135.

Katzer, F. 1903. Grundzüge der Geologie des Unteren Amazonasgebietes (des Staates Para in Brasilien). 296 pp. Max Weg. Verlag, Leipzig.

Kozlowski, R. 1923. Faune dévonienne de Bolivie. Annales de Paléontologie, 12, 1-112.

Kravtsov, A.G. in Besprozvannykh, N.I., Dubatolov, V.N., Kravtsov, A.G., Latypov, Yu.Ya. \& Spassky, N.Ya. 1975. Devonskie rugozy Taymyro-Kolymskoy provintsii. Akademiya Nauk SSSR, Sibirskoe Otdelenie, Trudy Instituta Geologii i Geofiziki 228, 1-172. [in Russian]

Lafuste, J. \& Tourneur, F. 1988. Microstructure du genre
Favosites Lamarck 1816 (Tabulata) et de favositides du Silurien, avec une révision du néotype de Favosites gotlandicus Lamarck 1816. Annales de la Société géologique de Belgique, 110(1987), 189-198.

LAmarCK, J.B. DE 1816. Histoire naturelle des Animaux sans vertèbres. II. 568 pp. Verdiére, Paris.

LANG, W.D. \& SMith, S. 1927. A Critical Revision of the Rugose Corals described by W. Lonsdale in Murchison's Silurian System. The Quarterly Journal of the Geological Society of London 83, 448-491.

DOI 10.1144/GSL.JGS.1927.083.01-05.18

Le Maître, D. 1952. La faune du Dévonien inférieur et moyen de la Saoura et des abords de 1'Erg El Djemel (SudOranais). Matériaux pour la carte géologique de l'Algérie. Paléontologie 12, 1-170.

Linnaeus, C. 1767. Systema naturae per regna tria naturae: secundum classes, ordines, genera, species, cum characteribus, differentiis, synonymis, locis 1(2), $12^{\text {th }}$ edition. 533-1327 pp. Holmiae, Stockholm.

DOI 10.5962/bhl.title.156772

Ludvigsen, R. 1987. Reef trilobites from the Formosa Limestone (Lower Devonian) of Southern Ontario. Canadian Journal of Earth Sciences 24, 676-688. DOI 10.1139/e87-066

MAY, A. 2006. Micheliniidae and Cleistoporidae (Anthozoa, Tabulata) from the Devonian of Spain. Bulletin of Geosciences 81(3), 163-172. DOI 10.3140/bull.geosci.2006.03.163

McLean, R.A. \& Copper, P. 2013. Rugose corals from the Early Silurian (Late Rhuddanian-Telychian) post-extinction recovery interval on Anticosti Island, eastern Canada. Palaeontographica Canadiana 33, 1-363.

Meek, F.B. 1868. Remarks on the Geology of the valley of the Mackenzie River, with Figures and descriptions of the Fossils from that region, in the Museum of the Smithsonian Institution, chiefly collected by the late Robert Kennicot, Esq. Transactions of the Chicago Academy of Sciences 1(1), 61-114. [date of imprint 1867]

Meek, F.B. \& Worthen, A.H. 1868. Geology and Palaeontology. Part II: Palaeontology. Geological Survey of Illinois III, 289-574.

Milne-Edwards, H. \& Haime, J. 1850. A Monograph of the British Fossil Corals. Introduction. 72 pp. Palaeontographical Society, London.

Morales, P.A. 1965. A contribution to the knowledge of the Devonian Faunas of Columbia. Boletin de Geologia 19, 51-94.

Morzadec, P., Mergl, M., Villarroel, C., Janvier, P. \& Racheboeuf, P.R. 2015. Trilobites and inarticulate brachiopods from the Devonian Floresta Formation of Columbia : a review. Bulletin of Geosciences 90(2), 331-358.

DOI 10.3140/bull.geosci.1515

Oliver, W.A. JR. 1977. Biogeography of late Silurian and Devonian rugose corals. Palaeogeography, Palaeoclimatology, Palaeoecology 22, 85-135.

DOI 10.1016/0031-0182(77)90014-1

Orbigny, A.M. D' 1850. Prodrome de Paléontologie stratigraphique universelle des animaux mollusques et rayonnés, I. 394 pp. V. Masson, Paris. 
Pedder, A.E.H. 2019. Systematics, biostratigraphy and significance of discoid and partly discoid corals from the Devonian of northwestern Canada, Ural Mountains Russia and southeastern Australia. Bulletin of Geosciences 94(2), 137-168. DOI 10.3140/bull.geosci.1734

Plusquellec, Y. 1976. Les polypiers - Tabulata, 183-225. In Lardeux, H. (coord.) Les Schistes et calcaires de SaintCéneré. Mémoires de la Société géologique et minéralogique de Bretagne 19.

Plusquellec, Y. 2007. Histoire naturelle des pleurodictyformes (Cnidaria, Tabulata, Dévonien) du Massif armoricain et des régions maghrébo-européennes principalement. Mémoires de la Société géologique et minéralogique de Bretagne 32, $1-137$.

Plusquellec, Y. \& Fernández-Martínez, E. 2007. Comments on the paper by A. May "Micheliniidae and Cleistoporidae (Anthozoa, Tabulata) from the Devonian of Spain". Bulletin of Geosciences 82(1), 85-89.

DOI 10.3140/bull.geosci.2007.01.85

Plusquellec, Y. \& Semenoff-Tian-Chansky, P. 1972. Révision de Combophyllum osismorum M.E. et H., 1850 (Tétracoralliaire dévonien). Bulletin du Muséum national d'Histoire naturelle 100, 411-460.

Plusquellec, Y. \& Tourneur, F. 1998. Persistance de Favositides microlamellaires (Cnidaria, Tabulata) dans le Dévonien. Comptes rendus de l'Académie des Sciences, Paris 326 , 283-289. DOI 10.1016/S1251-8050(97)86819-X

Plusquellec, Y., Desbiens, S. \& Gourvennec, R. 2011. Procteria (Pachyprocteria) vermifera n. sp., an unusual Hicetes-bearing species of tabulate coral from the lower Eifelian of the Gaspé Sandstones Group, Rimouski County (Québec, Canada). Canadian Journal of earth Sciences 48, 1530-1542. DOI 10.1139/e11-058

Plusquellec, Y., Tourneur, F. \& Fernández-Martínez, E. 2012. Tabulate corals (branching forms), 281-294. In RACHEBOEUF ET AL. New data on the Silurian-Devonian palaeontology and biostratigraphy of Bolivia. Bulletin of Geosciences 87(2). DOI 10.3140/bull.geosci.1248

Plusquellec, Y., Tourneur, F. \& Weyer, D. 2013. Revision of Pleurodictyum lonsdalii Rh. Richter, 1855, a representative of the genus Petridictyum Schindewolf, 1959 (Anthozoa,Tabulata, lower Devonian, Thuringia. Neues Jahrbuch für Geologie und Paläontologie, Abhandlungen 267/2, 193-214. DOI 10.1127/0077-7749/2013/0304

Powell, J.H. \& Scrutton, C.T. 1978. Variation in the Silurian tabulate coral Paleofavosites asper, and the status of Mesofavosites. Palaeontology 21(2), 307-319.

Roemer, F. 1876. Lethaea palaeozoica oder Beschreibung und abbildung der für die einzelnen Abtheilungen der palaeozoischen Formation bezeichnendsten Versteinerungen, Atlas. 68 pls Schweizerbarts'che Verlag, Stuttgart.

Schindewolf, O. 1959. Wümer und Korallen als synöken. Zur Kenntnis der Systeme Aspidosiphon/Heteropsammia und Hicetes/Pleurodictyum. Abhandlungen der mathematischNaturwissenschaftlichen Klasse (1958) 6, 261-327.

SchlÜter, C. 1889. Anthozoen des rheinischen Mittel Devon.
Abhandlungen zur geologischen Specialkarte von Preussen und den Thüringischen Staaten 8(4), 1-207.

Semenoff-Tian-Chansky, P. 1987. Sous-classe des tetracoralliaires, 765-781. In Doumenc, D. (ed.) Traité de Zoologie, tome III, Cnidaires Anthozoaires, fascicule 3. Masson, Paris.

SoKolov, B.S. 1950. Sistematika i istorija razvitija paleozojskich korallov Anthozoa Tabulata. Voprosy Paleontologii 1, 134-210. [in Russian]

Stauffer, C.R. 1952. The coral Microcyclus and some of its Devonian species. Geological Survey of Canada Bulletin 24, 1-33. DOI 10.4095/101525

Stumm, E.C. 1950. Corals of the Devonian Traverse Group of Michigan. Part III, Antholites, Pleurodictyum, and Procteria. Contributions from the Museum of Paleontology, University of Michigan 8(8), 205-220.

Stumm, E.C. 1967. Tabulate corals of the Silica Shale (Middle Devonian) of northwestern Ohio and southern Michigan. Contributions from the Museum of Paleontology, University of Michigan 21(4), 86-104.

Swartz, F.M. 1925. The Devonian Fauna of Bolivia. John Hopkins University Studies 6, 29-68.

Twenhofel, W.H. 1914. The Anticosti Island Faunas. Museum Bulletin, Geological Series, Canada Geological Survey 19(3), 1-39. DOI 10.5962/bhl.title.63998

Uyeno, T.T., Telford, P.G. \& SAnford, B.V. 1982. Devonian conodonts and stratigraphy of southern Ontario. Geological Survey of Canada, Bulletin 332, 1-55. DOI 10.4095/119432

VeriLl, A.E. 1865. Classification of polyps (Extract condensed from a synopsis of the polypi of the North Pacific Exploring Expedition, under captains Ringgold and Rogers, U.S.N. Essex Institute Proceedings 4, 145-149.

Waagen, W.H. \& Wentzel, J. 1886. Salt Range fossils, vol. 1, Productus Limestone fosssils; 6, Coelenterata. Palaeontologica Indica 13, 835-924.

Wang, G., Percival, I.G. \& Li, R. 2015. Remarks on the pattern of septal insertion in rugose corals. Alcheringa 39, 388-393. DOI 10.1080/03115518.2015.1008787

Wedekind, R. 1937. Einfürung in die Grundlagen der historischen Geologie. II. Band. Mikrobiostratigraphie, Die Korallen- und Foraminiferenzeit. viii +136 pp. Ferdinand Enke, Stuttgart.

Weissermel, W. 1941a. Korallen aus dem Unterdevon des östlichen und westlichen Schiefergebirges Thüringens. Die Korallen des Thüringischen Devons. Teil 2. Zeitschrift der Deutschen Geologischen Gesellschaft 93, 163-212.

Weissermel, W. 1941b. Favositen aus schiefrigem Mittel- und Unter-Devon im Rheinischen Schiefergebirge. Senkenbergiana 23(1/3), 177-182.

WeYER, D. 1970. Granulidictyum Schindewolf, 1959 (Anthozoa, Tabulata) im Unterdevon des Thüringer Schiefergebirges. Geologie 19(9), 1115-1121.

Weyer, D. 2014. Thurispina nov. gen. (Anthozoa, Rugosa) from the Upper Famennian of Thuringia (Germany). Freiberger Forschungshefte C 548, 109-151. 